\section{Effects of Flurprimidol, Mefluidide, and Soil Moisture on St. Augustine- grass Evapotranspiration Rate}

\author{
Robert L. Green', Ki S. Kim², and James B. Beard ${ }^{3}$ \\ Department of Soil and Crop Sciences, Texas A\&M University, College \\ Station, TX 77843-2474
}

Additional index words. leaf extension rate, plant growth regulator, Stenotaphrum secundatum, turf quality, water use rate

Abstract. The objective of this study was to determine the effects of two plant growth regulators (PGR) and two soil moisture levels (SML) on the evapotranspiration (ET) rate, leaf extension rate (LER), and visual turfgrass quality of 'Texas Common' St. Augustinegrass [Stenotaphrum secundatum (Walt.) Kuntze] grown under glasshouse conditions in black plastic minilysimeters. Treatments included mefluidide at $0.42 \mathrm{~kg} \cdot \mathrm{ha}^{-1}$, flurprimidol at $0.84 \mathrm{~kg} \cdot \mathrm{ha}^{-1}$, and no PGR, each grown under optimal ( $-0.01 \mathrm{MPa}$ ) or suboptimal (- $0.8 \mathrm{MPa})$ SML. Both flurprimidol and mefluidide significantly affected ET rate, LER, and turfgrass quality, whereas the durations of the responses to both PGR treatments were affected by SML. For both SML, the durations of significant reduction in ET rate, LER, and turfgrass quality were longer for flurprimidol than for mefluidide. Application of either PGR at either SML caused a significant reduction in ET rate averaging $18 \%$ and a significant reduction in LER averaging $83 \%$. Flurprimidol was more effective than metluidide in terms of ET rate and LER reduction. However, the considerably longer duration of reduced turfgrass quality of flurprimidoltreated turf was a negative effect. Chemical names used: $\alpha-(1$-methylethyl)- $\alpha$-[4-trifluoromethoxy)phenyl]-5-pyrimidinemethanol (flurprimidol) and $N$ - [2,4-dimethyl-5[[(trifluoromethyl) sulfonyl]amino]phenyI] acetamide (mefluidide).

Plant growth regulators (PGR) have been effective in suppressing shoot growth and/or seedhead development of cool-season (Beard, 1973; Christians, 1985; Christians and Nau, 1984; Dernoeden, 1984; McCarty et al., 1985) and warm-season turfgrasses (Batten and Beard, 1982; Kelly et al., 1983; Rogers et all 1987; Wu et al., 1976). Since water costs are projected to increase and water availability to decrease, research is needed concerning methods to reduce turfgrass water use. Shoot growth rate and evapotranspiration (ET) rate of 'Texas Common' St. Augustinegrass and 'Tifway' bermudagrass [Cynodon dactylon (L.) Pers. $\times$ C. transvaalensis Davy] were reduced by applications of PGRs (Johns and Beard, 1982) and for cool-season perennial grasses (Doyle and Sherman, 1985; Mathias et al., 1971). Vertical leaf elongation rate was a prime determinant for assessment of ET rate of turfgrasses (Kim and Beard, 1988; Sherman, 1986; Sifers et al., 1987). The objectives of this study were to determine the effects of PGR and

Received for publication 7 Nov. 1988. Contribution from the Texas Agricultural Experiment Station Journal Article TA 24124. This study was partially supported by a grant from the U.S. Golf Association. The cost of publishing this paper was defrayed in part by the payment of page charges. Under postal regulations, this paper therefore must be hereby marked advertisement solely to indicate this fact.

${ }^{1}$ Postdoctoral Research Associate.

${ }^{2}$ Former Research Assistant.

${ }^{3}$ Professor. soil moisture level (SML) on ET rate, leaf extension rate (LER), and turfgrass quality of 'Texas Common' St. Augustinegrass.

During 26 June 1986, mature turf plugs (20 cm in diameter) of 'Texas Common' St. Augustinegrass were harvested from a field location at the Texas A\&M Univ. Turfgrass Field Research Laboratory. The root system

Table 1. Effects of flurprimidol and mefluidide on ET rates of St. Augustinegrass maintained under two soil moisture levels in a glasshouse.

\begin{tabular}{|c|c|c|c|c|c|c|}
\hline \multirow{3}{*}{$\begin{array}{l}\text { Wecks } \\
\text { following } \\
\text { treatments } \\
\end{array}$} & \multicolumn{6}{|c|}{ Evapotranspiration rate $\left(\mathrm{mm} \cdot \mathrm{day}^{-1}\right)$} \\
\hline & \multicolumn{3}{|c|}{ Optimal soil moisture } & \multicolumn{3}{|c|}{ Suboptimal soil moisture } \\
\hline & Untreated & Flurprimidol & Mefluidide & Untreated & Flurprimidol & Mefluidide \\
\hline $\begin{array}{l}0 \\
2 \\
3 \\
4 \\
5\end{array}$ & $\begin{array}{r}8.0 \mathrm{a}^{\mathrm{z}} \\
8.7 \mathrm{a} \\
11.8 \mathrm{a} \\
10.5 \mathrm{a} \\
9.1 \mathrm{a}\end{array}$ & $\begin{array}{c}7.9 \mathrm{a} \\
8.0 \mathrm{ab} \\
10.2 \mathrm{~b} \\
9.1 \mathrm{~b} \\
7.6 \mathrm{~b}\end{array}$ & $\begin{array}{l}8.0 \mathrm{a} \\
7.1 \mathrm{~b} \\
8.6 \mathrm{c} \\
8.5 \mathrm{~b} \\
7.7 \mathrm{~b}\end{array}$ & $\begin{array}{l}5.8 \mathrm{a} \\
7.0 \mathrm{a} \\
9.0 \mathrm{a} \\
8.8 \mathrm{a} \\
7.9 \mathrm{a}\end{array}$ & $\begin{array}{l}5.8 \mathrm{a} \\
6.1 \mathrm{~b} \\
7.4 \mathrm{~b} \\
7.3 \mathrm{~b} \\
6.3 \mathrm{~b}\end{array}$ & $\begin{array}{l}5.8 \mathrm{a} \\
6.2 \mathrm{~b} \\
7.6 \mathrm{~b} \\
7.5 \mathrm{~b} \\
6.1 \mathrm{~b}\end{array}$ \\
\hline $\begin{array}{c}6 \\
7 \\
8 \\
9 \\
10\end{array}$ & $\begin{array}{c}8.4 \mathrm{a} \\
8.7 \mathrm{ab} \\
10.1 \mathrm{a} \\
3.1 \mathrm{ab} \\
7.7 \mathrm{ab}\end{array}$ & $\begin{array}{l}6.8 \mathrm{~b} \\
7.6 \mathrm{~b} \\
8.7 \mathrm{~b} \\
2.7 \mathrm{~b} \\
6.9 \mathrm{~b}\end{array}$ & $\begin{array}{r}7.8 \mathrm{a} \\
9.2 \mathrm{a} \\
10.6 \mathrm{a} \\
3.5 \mathrm{a} \\
8.3 \mathrm{a}\end{array}$ & $\begin{array}{l}7.2 \mathrm{a} \\
7.7 \mathrm{a} \\
8.4 \mathrm{a} \\
2.7 \mathrm{a} \\
6.8 \mathrm{a}\end{array}$ & $\begin{array}{l}5.8 \mathrm{ab} \\
6.3 \mathrm{c} \\
6.8 \mathrm{~b} \\
2.0 \mathrm{~b} \\
5.5 \mathrm{~b}\end{array}$ & $\begin{array}{l}5.0 \mathrm{~b} \\
6.7 \mathrm{~b} \\
7.6 \mathrm{ab} \\
2.7 \mathrm{a} \\
6.9 \mathrm{a}\end{array}$ \\
\hline $\begin{array}{l}12 \\
13 \\
14 \\
15\end{array}$ & $\begin{array}{l}6.8 \mathrm{a} \\
5.6 \mathrm{a} \\
3.3 \mathrm{a} \\
7.8 \mathrm{a}\end{array}$ & $\begin{array}{l}6.6 \mathrm{a} \\
5.5 \mathrm{a} \\
3.2 \mathrm{a} \\
7.8 \mathrm{a}\end{array}$ & $\begin{array}{l}7.3 \mathrm{a} \\
6.0 \mathrm{a} \\
3.4 \mathrm{a} \\
8.7 \mathrm{a}\end{array}$ & $\begin{array}{l}6.1 \mathrm{a} \\
5.2 \mathrm{a} \\
3.1 \mathrm{a} \\
7.4 \mathrm{~b}\end{array}$ & $\begin{array}{l}5.2 \mathrm{~b} \\
4.5 \mathrm{~b} \\
2.6 \mathrm{a} \\
6.1 \mathrm{c}\end{array}$ & $\begin{array}{l}6.3 \mathrm{a} \\
5.4 \mathrm{a} \\
3.2 \mathrm{a} \\
8.3 \mathrm{a}\end{array}$ \\
\hline $\begin{array}{l}16 \\
17 \\
18 \\
19 \\
20 \\
21\end{array}$ & $\begin{array}{l}7.0 \mathrm{a} \\
3.4 \mathrm{a} \\
5.2 \mathrm{a} \\
2.2 \mathrm{a} \\
5.1 \mathrm{a} \\
4.0 \mathrm{a}\end{array}$ & $\begin{array}{l}6.9 \mathrm{a} \\
3.5 \mathrm{a} \\
5.0 \mathrm{a} \\
2.2 \mathrm{a} \\
5.0 \mathrm{a} \\
3.9 \mathrm{a}\end{array}$ & $\begin{array}{l}8.2 \mathrm{a} \\
3.5 \mathrm{a} \\
5.2 \mathrm{a} \\
2.3 \mathrm{a} \\
4.8 \mathrm{a} \\
3.9 \mathrm{a}\end{array}$ & $\begin{array}{l}6.5 \mathrm{a} \\
3.6 \mathrm{a} \\
5.6 \mathrm{a} \\
2.3 \mathrm{a} \\
6.0 \mathrm{a} \\
4.1 \mathrm{a}\end{array}$ & $\begin{array}{l}5.1 \mathrm{~b} \\
3.1 \mathrm{~b} \\
4.8 \mathrm{a} \\
2.1 \mathrm{a} \\
5.8 \mathrm{a} \\
4.2 \mathrm{a}\end{array}$ & $\begin{array}{l}7.2 \mathrm{a} \\
3.7 \mathrm{a} \\
5.7 \mathrm{a} \\
2.3 \mathrm{a} \\
5.9 \mathrm{a} \\
4.2 \mathrm{a}\end{array}$ \\
\hline
\end{tabular}

${ }^{2}$ Means are the average of three replicates. Mean separation in rows of the same soil moisture by Duncan's multiple range test, $P=0.05$. was severed $5 \mathrm{~mm}$ from the crown and the turf plugs were thoroughly washed to eliminate soil. The turfs were then transplanted onto a predetermined weight of fritted clay ('Absorb-N-Dry', Balcones Mineral Corp., Flatonia, Texas) contained in black plastic minilysimeters $(22 \mathrm{~cm}$ in diameter and 21.5 $\mathrm{cm}$ deep). The turfs were fertilized biweekly during the study with a nutrient solution $(23 \mathrm{~N}-$ $8.4 \mathrm{P}-14.1 \mathrm{~K}$ plus micronutrients) at $4.88 \mathrm{~g}$ $\mathrm{N} / \mathrm{m}^{2}$ per month $\left(1 \mathrm{lb} \mathrm{N} / 1000 \mathrm{ft}^{2}\right.$ per month) and mowed weekly at a 76-mm cutting height via a reel mower with clippings removed. Air maxima and minima in the glasshouse did not exceed 35 and $24 \mathrm{C}$.

Three weeks before spraying PGR treatments, two SML treatments, $-0.01 \mathrm{MPa}$ (optimal moisture) and $-0.8 \mathrm{MPa}$ (suboptimal moisture), were imposed on the minilysimeters by gradual adjustment over 2 weeks to a precalculated weight. This was based on the curve of volumetric water content to soil pressure potential that was previously generated for fritted clay (Van Bavel et al., 1978) and total weight was adjusted for fresh plant weight. Fresh plant weight was estimated by harvesting and weighing plants from two representative minilysimeters. The minilysimeters were maintained at their appropriate SML for the remainder of the study by adding distilled water every 2 days, occasionally every 3 days, to compensate for evapotranspirational water loss; the average water loss of all minilysimeters for the duration of the study was $164 \mathrm{ml} \cdot$ day $^{-1}$ Nutrient solution was added instead of water when fertilization was required. Maintaining optimal and suboptimal SML was a primary objective in this study. However, frequent additions of small amounts of water would not necessarily maintain a uniform soil moisture tension for the entire root zone, but would favor a more 
Table 2. Effects of flurprimidol and mefluidide on the leaf extension rates of St. Augustinegrass maintained under two soil moisture levels in a glasshouse.

\begin{tabular}{|c|c|c|c|c|c|c|}
\hline \multirow{3}{*}{$\begin{array}{l}\text { Weeks } \\
\text { following } \\
\text { treatment }\end{array}$} & \multicolumn{6}{|c|}{ Leaf extension rate $\left(\mathrm{mm} \cdot\right.$ day $\left.^{-1}\right)$} \\
\hline & \multicolumn{3}{|c|}{ Optimal soil moisture } & \multicolumn{3}{|c|}{ Suboptimal soil moisture } \\
\hline & Untreated & Flurprimidol & Mefluidide & Untreated & Flurprimidol & Mefluidide \\
\hline $\begin{array}{l}2 \\
3 \\
4 \\
5\end{array}$ & $\begin{array}{l}9.8 \mathrm{a}^{\mathrm{z}} \\
7.8 \mathrm{a} \\
6.1 \mathrm{a} \\
4.4 \mathrm{a}\end{array}$ & $\begin{array}{l}4.0 \mathrm{~b} \\
0.4 \mathrm{~b} \\
0.1 \mathrm{~b} \\
0.0 \mathrm{~b}\end{array}$ & $\begin{array}{l}1.4 \mathrm{~b} \\
0.1 \mathrm{~b} \\
0.2 \mathrm{~b} \\
0.5 \mathrm{~b}\end{array}$ & $\begin{array}{l}5.8 \mathrm{a} \\
4.6 \mathrm{a} \\
4.0 \mathrm{a} \\
3.6 \mathrm{a}\end{array}$ & $\begin{array}{l}2.3 \mathrm{~b} \\
0.7 \mathrm{~b} \\
0.3 \mathrm{~b} \\
0.1 \mathrm{~b}\end{array}$ & $\begin{array}{l}1.5 \mathrm{~b} \\
0.5 \mathrm{~b} \\
0.1 \mathrm{~b} \\
0.0 \mathrm{~b}\end{array}$ \\
\hline $\begin{array}{c}6 \\
7 \\
8 \\
9 \\
10\end{array}$ & $\begin{array}{l}3.9 \mathrm{a} \\
6.1 \mathrm{~b} \\
6.5 \mathrm{~b} \\
7.0 \mathrm{~b} \\
6.8 \mathrm{~b}\end{array}$ & $\begin{array}{l}0.0 \mathrm{c} \\
0.1 \mathrm{c} \\
0.6 \mathrm{c} \\
2.2 \mathrm{c} \\
2.8 \mathrm{c}\end{array}$ & $\begin{array}{r}1.8 \mathrm{~b} \\
8.6 \mathrm{a} \\
10.2 \mathrm{a} \\
10.5 \mathrm{a} \\
10.3 \mathrm{a}\end{array}$ & $\begin{array}{l}2.8 \mathrm{a} \\
5.8 \mathrm{a} \\
6.2 \mathrm{a} \\
7.1 \mathrm{a} \\
7.0 \mathrm{~b}\end{array}$ & $\begin{array}{l}0.1 \mathrm{~b} \\
0.1 \mathrm{c} \\
0.1 \mathrm{~b} \\
0.4 \mathrm{~b} \\
0.7 \mathrm{c}\end{array}$ & $\begin{array}{l}0.1 \mathrm{~b} \\
3.7 \mathrm{~b} \\
6.5 \mathrm{a} \\
7.3 \mathrm{a} \\
9.1 \mathrm{a}\end{array}$ \\
\hline $\begin{array}{l}12 \\
13 \\
14 \\
15\end{array}$ & $\begin{array}{l}4.3 \mathrm{~b} \\
5.1 \mathrm{ab} \\
4.7 \mathrm{ab} \\
4.2 \mathrm{a}\end{array}$ & $\begin{array}{l}3.4 \mathrm{~b} \\
3.7 \mathrm{~b} \\
3.3 \mathrm{~b} \\
2.9 \mathrm{~b}\end{array}$ & $\begin{array}{l}6.7 \mathrm{a} \\
6.5 \mathrm{a} \\
6.0 \mathrm{a} \\
4.4 \mathrm{a}\end{array}$ & $\begin{array}{l}3.0 \mathrm{~b} \\
4.1 \mathrm{~b} \\
4.6 \mathrm{a} \\
3.6 \mathrm{a}\end{array}$ & $\begin{array}{l}0.6 \mathrm{c} \\
1.0 \mathrm{c} \\
0.8 \mathrm{~b} \\
0.9 \mathrm{~b}\end{array}$ & $\begin{array}{l}5.8 \mathrm{a} \\
5.5 \mathrm{a} \\
5.8 \mathrm{a} \\
4.4 \mathrm{a}\end{array}$ \\
\hline $\begin{array}{l}16 \\
17 \\
18 \\
19 \\
20 \\
21\end{array}$ & $\begin{array}{l}8.5 \mathrm{~b} \\
8.4 \mathrm{a} \\
8.2 \mathrm{ab} \\
9.0 \mathrm{a} \\
4.7 \mathrm{a} \\
6.6 \mathrm{a}\end{array}$ & $\begin{array}{l}8.4 \mathrm{~b} \\
7.5 \mathrm{a} \\
7.6 \mathrm{~b} \\
8.7 \mathrm{a} \\
4.5 \mathrm{ab} \\
6.5 \mathrm{a}\end{array}$ & $\begin{array}{r}10.2 \mathrm{a} \\
8.8 \mathrm{a} \\
9.0 \mathrm{a} \\
8.7 \mathrm{a} \\
4.1 \mathrm{~b} \\
6.0 \mathrm{a}\end{array}$ & $\begin{array}{l}9.1 \mathrm{a} \\
9.4 \mathrm{a} \\
9.8 \mathrm{a} \\
9.3 \mathrm{a} \\
4.7 \mathrm{~b} \\
5.6 \mathrm{a}\end{array}$ & $\begin{array}{l}3.0 \mathrm{~b} \\
3.6 \mathrm{~b} \\
4.3 \mathrm{~b} \\
6.1 \mathrm{~b} \\
4.4 \mathrm{~b} \\
5.7 \mathrm{a}\end{array}$ & $\begin{array}{r}11.2 \mathrm{a} \\
10.3 \mathrm{a} \\
10.9 \mathrm{a} \\
10.0 \mathrm{a} \\
5.9 \mathrm{a} \\
6.9 \mathrm{a}\end{array}$ \\
\hline
\end{tabular}

${ }^{2}$ Means are the average of three replicates. Mean separation in rows of the same soil moisture by Duncan's multiple range test, $P=0: 05$.

Table 3. Effects of flurprimidol and mefluidide on the turfgrass quality of St. Augustinegrass maintained under two soil moisture levels in a glasshouse.

\begin{tabular}{|c|c|c|c|c|c|c|}
\hline \multirow{3}{*}{$\begin{array}{l}\text { Weeks } \\
\text { following } \\
\text { treatment }\end{array}$} & \multicolumn{6}{|c|}{ Turfgrass quality ${ }^{2}$} \\
\hline & \multicolumn{3}{|c|}{ Optimal soil moisture } & \multicolumn{3}{|c|}{ Suboptimal soil moisture } \\
\hline & Untreated & Flurprimidol & Mefluidide & Untreated & Flurprimidol & Mefluidide \\
\hline $\begin{array}{l}3 \\
5 \\
7 \\
9\end{array}$ & $\begin{array}{l}8.7 \mathrm{a}^{\mathrm{y}} \\
8.7 \mathrm{a} \\
8.7 \mathrm{a} \\
7.7 \mathrm{a}\end{array}$ & $\begin{array}{l}8.0 \mathrm{a} \\
7.3 \mathrm{~b} \\
6.7 \mathrm{~b} \\
6.3 \mathrm{~b}\end{array}$ & $\begin{array}{l}8.7 \mathrm{a} \\
7.0 \mathrm{~b} \\
7.7 \mathrm{ab} \\
7.0 \mathrm{ab}\end{array}$ & $\begin{array}{r}9.0 \mathrm{a} \\
8.7 \mathrm{a} \\
8.3 \mathrm{a} \\
8.0 \mathrm{a}\end{array}$ & $\begin{array}{l}5.3 \mathrm{~b} \\
7.0 \mathrm{~b} \\
6.0 \mathrm{~b} \\
5.3 \mathrm{c}\end{array}$ & $\begin{array}{l}8.3 \mathrm{a} \\
7.3 \mathrm{ab} \\
7.0 \mathrm{~b} \\
7.0 \mathrm{~b}\end{array}$ \\
\hline $\begin{array}{l}14 \\
15 \\
16 \\
17 \\
18 \\
19 \\
21\end{array}$ & $\begin{array}{l}8.7 \mathrm{a} \\
8.3 \mathrm{ab} \\
8.7 \mathrm{a} \\
8.7 \mathrm{a} \\
8.7 \mathrm{a} \\
8.7 \mathrm{a} \\
9.0 \mathrm{a}\end{array}$ & $\begin{array}{l}7.3 \mathrm{~b} \\
7.3 \mathrm{~b} \\
8.3 \mathrm{a} \\
8.3 \mathrm{a} \\
8.7 \mathrm{a} \\
9.0 \mathrm{a} \\
9.0 \mathrm{a}\end{array}$ & $\begin{array}{l}9.0 \mathrm{a} \\
9.0 \mathrm{a} \\
9.0 \mathrm{a} \\
9.0 \mathrm{a} \\
9.0 \mathrm{a} \\
9.0 \mathrm{a} \\
9.0 \mathrm{a}\end{array}$ & $\begin{array}{l}8.7 \mathrm{a} \\
8.0 \mathrm{a} \\
9.0 \mathrm{a} \\
9.0 \mathrm{a} \\
9.0 \mathrm{a} \\
9.0 \mathrm{a} \\
9.0 \mathrm{a}\end{array}$ & $\begin{array}{l}6.0 \mathrm{~b} \\
6.3 \mathrm{~b} \\
6.7 \mathrm{~b} \\
6.7 \mathrm{~b} \\
7.7 \mathrm{~b} \\
8.0 \mathrm{a} \\
8.7 \mathrm{a}\end{array}$ & $\begin{array}{l}8.7 \mathrm{a} \\
8.7 \mathrm{a} \\
9.0 \mathrm{a} \\
9.0 \mathrm{a} \\
9.0 \mathrm{a} \\
9.0 \mathrm{a} \\
9.0 \mathrm{a}\end{array}$ \\
\hline
\end{tabular}

${ }^{2}$ Visual turfgrass quality rated on a scale of 1 to 9 , with $9=$ best.

${ }^{y}$ Means are the average of three replicates. Mean separation in rows of the same soil moisturc by Duncan's multiple range test, $P=0.05$.

moist upper and a drier lower root zone. On 14 July 1987, the turf plugs were treated in a laboratory spray chamber (Bouse and Bovey, 1967) calibrated for a finished spray volume of 467.6 liter $\cdot$ ha $^{-1}$ with mefluidide and flurprimidol applied at a rate of 0.42 and $0.84 \mathrm{~kg} \cdot \mathrm{ha}^{-1}$, respectively. There were three replicates for each SML-PGR treatment combination.

Evapotranspiration rate for $24 \mathrm{hr}$ was measured weekly over 21 weeks after PGR treatment by using the minilysimetry technique combined with the water balance method described by Kim and Beard (1988). These determinations were made between days 6 and 7 of the weekly mowing schedule, while LER was determined for the entire 7 days. LER was determined by calculating the difference between shoot height of 10 leaf blades, measured from the top edge of the minilysimeter, immediately following mowing and then 7 days later, before mow- a CRD by SML and week. Data presented in Tables 1-3 were extracted from these ANOVAs.

Flurprimidol and mefluidide significantly affected ET rate, LER, and turfgrass quality of St. Augustinegrass, whereas duration of both PGR treatments was affected by the SML (Tables 1-3). For both SML, the durations of significant reduction of ET rate, LER, and turfgrass quality were longer for flurprimidol than for mefluidide. Previous work with Kentucky bluegrass (Poa pratensis L.) showed that flurprimidol suppressed shoot growth and reduced turfgrass quality for a longer duration than mefluidide (Christians, 1985; Dernoeden, 1984). Flurprimidol only suppresses growth, while mefluidide suppresses growth and development (Kaufmann, 1986).

Flurprimidol significantly reduced ET rate for 5 weeks (weeks 3-8) at optimaal SML and for 15 weeks (weeks 2-17) at suboptimal SML (Table 1). Evapotranspiration rate was reduced by an average of $15 \%$ and $18 \%$ at optimal and suboptimal SML, respectively. Mefluidide significantly reduced ET rate for 3 weeks (weeks 2-5) at optimal SML and for 5 weeks (weeks 2-7) at suboptimal SML. Evapotranspiration rate was reduced by an average of 20\% and 18\% at optimal and suboptimal SML, respectively. There was a trend for enhanced ET rate for 9 weeks (weeks 716) by mefluidide, but ET rate data did not vary significantly from untreated turf. Enhanced ET rate via increased leaf growth rates following growth suppression also was reported for Kentucky bluegrass treated with mefluidide (Doyle and Shearman, 1985).

At optimal SML, flurprimidol significantly reduced LER for 8 weeks (weeks 210) and at suboptimal SML for 17 weeks (weeks 2-19) (Table 2). LER was reduced by an average $85 \%$ and $79 \%$ at optimal and suboptimal SML, respectively. At optimal SML, mefluidide significantly reduced LER for 4 weeks (weeks 2-6), with an average reduction of $85 \%$, but also caused a significant enhancement for 5 weeks (weeks 712 ), with an average enhancement of $51 \%$. At suboptimal SML, mefluidide significantly reduced LER for 5 weeks (weeks 27 ), with an average reduction of $82 \%$, but caused a significant enhancement for 3 weeks (weeks 10-13), with an average enhancement of $52 \%$.

At optimal SML, flurprimidol caused a significant reduction in turfgrass quality for 9 weeks (weeks 5-14) and at suboptimal SML for 15 weeks (weeks 3-18) (Table 3). Average reduction in turfgrass quality was $18 \%$ and $27 \%$ at optimal and suboptimal SML, respectively. Average turfgrass quality during the period of significant reduction was 6.9 and 6.3 at optimal and suboptimal SML, respectively. At optimal SML, mefluidide caused a significant reduction in turfgrass quality for 1 week (week 5) and at suboptimal SML for 2 weeks (weeks 7-9). Average reduction in turfgrass quality was $20 \%$ and $15 \%$ at optimal and suboptimal SML, respectively. Average turfgrass quality during the period of significant reduction was 7.0 at optimal and suboptimal SML. Turfgrass 
quality increased as shoot growth resumed following PGR-induced growth suppression.

PGRs were very effective in reducing the ET rate and LER in St. Augustinegrass. Application of either PGR at either SML caused a reduction in ET rate by an average 18\%, but the duration of significant activity varied with the PGR and SML. Duration of significant ET rate reduction was greater for flurprimidol than for mefluidide. Both PGRs had a longer duration of significant ET rate reduction at suboptimal SML, and the duration for flurprimidol was increased more by the suboptimal SML than for mefluidide.

Application of either PGR at either SML reduced LER by an average $83 \%$, but the duration of significant activity varied with PGR and SML. Duration of significant LER reduction was greater for flurprimidol than for mefluidide. Both PGRs had a longer duration of significant LER reduction at suboptimal SML. The duration for flurprimidol was increased more by the suboptimal SML than for mefluidide. In terms of shoot growth, previous work with bermudagrass reported no or minimal effect of SML on PGR activity (Rogers et al., 1987; Wu et al., 1976). Application of mefluidide caused a significant LER enhancement (average 52\% enhancement) of similar duration as its preceding LER reduction.

Flurprimidol was a more effective PGR than mefluidide for St. Augustinegrass in terms of duration of ET rate and LER reduction. However, the considerably longer duration of reduced turfgrass quality of flurprimidol-treated turf is a considerable limitation. Future studies should assess lower rates of application for flurprimidol. Both PGRs were more effective at the lower soil moisture level. Thus, turfgrass cultural programs that include the use of PGRs should reduce the amount of irrigation to gain maximum benefit from the PGR.

\section{Literature Cited}

Batten, S.M. and J.B. Beard. 1982. Assessment of growth regulators for use in chemical trimming. Texas Turfgrass Research-1982. PR4054. p. 76-77.

Beard, J.B. 1973, Turfgrass: Science and culture. Prentice-Hall, Englewood Cliffs, N.J.

Bouse, L.F. and R.W. Bovey. 1967. A laboratory sprayer for potted plants. Weed Sci. 15:89-91.

Christians, N.E. 1985. Response of Kentucky bluegrass to four growth retardants. J. Amer. Soc. Hort. Sci. 110:765-769.

Christians, N.E. and J. Nau. 1984. Growth retardant effects on three turfgrass species. J. Amer. Soc. Hort. Sci. 109:45-47.

Dernoeden, P.M. 1984. Four-year response of a Kentucky bluegrass-red fescue turf to plant growth retardants. Agron. J. 76:807-813.

Doyle, J.M. and R.C. Shearman. 1985. Plant growth regulator effects on evapotranspiration of a Kentucky bluegrass turf. Agron. Abstr. p. 115.

Johns, D., Jr., and J.B. Beard. 1982. Water conservation-A potentially new dimension in the use of growth regulators. Texas Turfgrass Research-1982. PR-4040. p. 35.

Kaufmann, J.E. 1986. The role of PGR science in chemical vegetation control. Proc. Plant Growth Regulat. Soc. Amer. p. 2-14.
Kelly, C.A., K.L. Walker, J.R. Abernathy, and C.W. Wendt. 1983. The influence of growth regulators on common bermudagrass. Texas Turfgrass Research-1983. PR-4168. p. 111125.

Kim, K.S. and J.B. Beard. 1988. Comparative turfgrass evapotranspiration rates and associated plant morphological characteristics. Crop Sci. 28:328-331.

McCarty, L.B., J.M. DiPaola, W.M. Lewis, and W.B. Gilbert. 1985. Tall fescue response to plant growth retardants and fertilizer sources. Agron. J. 77:476-480.

Mathias, E. L., O.L. Bennett, G.A. Jung, and P.E. Lundberg. 1971. Effect of two growth-regulating chemicals on yield and water use of three perennial grasses. Agron. J. 63:480-483.
Rogers, J.N., III, E.M. Miller, and J.W. King. 1987. Growth retardation of bermudagrass with metsulfuron methyl and sulfometuron methyl. Agron. J. 79:225-229.

Sherman, R.C. 1986. Kentucky bluegrass cultivar evapotranspiration rates. HortScience 21:455457.

Sifers, S.I., J.B. Beard, and K.S. Kim. 1987. Criteria for visual prediction of low water use rates of bermudagrass cultivars. Texas Turf. grass Research-1986. PR-4519. p. 22-23.

Van Bavel, C.H.M., R. Lascano, and D.R. Wilson. 1978. Water relations in fritted clay. Soil Sci. Soc. Amer. J. 42:657-659.

Wu, C., H.R. Myers, and P.W. Santelmann. 1976. Chemical retardation of bermudagrass turf. Agron. J. 68:949-952. 